\title{
Pengembangan Podcast dengan Model Addie pada Materi Cerita Rakyat Sebagai Sumber Belajar Berbasis Audio
}

\author{
Zam Zam Jamaludin*, Erwin Rahayu Saputra \\ Jurusan Pendidikan Guru Sekolah Dasar, Universitas Pendidikan Indonesia \\ *Corresponding Author. Email: zamzamjamaludin.tsm@gmail.com
}

\begin{abstract}
This study aims to produce a podcast as an audio-based learning resource and determine its feasibility. This research was conducted using the ADDIE development model (Analysis, Design, Development, Implementation, Evaluation) on folklore material. In this study, data were collected through observation and interviews, questionnaires and tests, which were then analyzed by paired two-sample t-test. The results of the content expert's review stated that the podcast developed was appropriate. The results of the expert review of audio-based learning resources stated that it was very good, while the review of learning design experts stated that the podcast developed was in the good category. Student responses in field trials showed student responses to the product were very good, which was $92.11 \%$. The results of the calculation of student achievement before and after using interactive multimedia based on the results of the t-test carried out gave the results of t-count $=0.001(<\mathrm{a}=00.5)$. The average result of the posttest of students is 86.92 , which is above the KKM value set at 75 . This shows that the development of podcasts as an audio-based learning resource is feasible to use in the learning process for folklore material.
\end{abstract}

\begin{abstract}
Abstrak: Penelitian ini bertujuan untuk menghasilkan podcast sebagai sumber belajar berbasis audio dan mengetahui kelayakannya. Penelitian ini dilakukan dengan menggunakan model pengembangan ADDIE (Analysis, Design, Development, Implementation, Evaluation) pada materi cerita rakyat. Dalam penelitian ini, data dikumpulkan melalui observasi dan wawancara, kuisioner dan tes, yang selanjutnya dianalisis dengan Uji-t dua sampel berpasangan. Hasil tinjauan ahli isi menyatakan bahwa podcast yang dikembangkan sudah sesuai. Hasil tinjauan ahli sumber belajar berbasis audio menyatakan sangat baik, sedangkan tinjauan ahli desain pembelajaran menyatakan podcast yang dikembangkan pada kategori baik. Tanggapan siswa pada uji coba dilapangan memperlihatkan tanggapan siswa terhadap produk sangat baik yaitu sebesar $92,11 \%$. Hasil perhitungan dari prestasi belajar siswa sebelum dan sesudah menggunakan multimedia interaktif berdasarkan hasil uji-t yang dilakukan memberikan hasil t-hitung=0,001 $(<\mathrm{a}=00,5)$. Hasil rata-rata posttest siswa sebesar masing-masing 86,92 berada diatas nilai KKM yang ditetapkan sebesar 75. Hal ini menunjukan bahwa pengembangan podcast sebagai sumber belajar berbasis audio telah layak digunakan dalam proses pembelajaran untuk materi cerita rakyat.
\end{abstract}

How to Cite: Jamaludin, Z., \& Saputra, E. (2021). Pengembangan Podcast dengan Model Addie pada Materi Cerita Rakyat Sebagai Sumber Belajar Berbasis Audio. Jurnal Teknologi Pendidikan : Jurnal Penelitian dan Pengembangan Pembelajaran, 6(2), 120-127. doi:https://doi.org/10.33394/jtp.v6i2.3887

https://doi.org/10.33394/jtp.v6i2.3887

This is an open-access article under the CC-BY-SA License.

\section{Pendahuluan}

Tahun ajaran baru 2020/2021 Kementerian Pendidikan dan Kebudayaan atau Kemendikbud menerbitkan Surat Edaran Nomor 15 Tahun 2020 tentang Pedoman Penyelenggaraan belajar di rumah. Dalam masa darurat penyebaran covid-19. Dalam hal ini metode dan sumber pelaksanaan belajar dilaksanakan dengan pembelajaran jarak jauh yang 
dibagi dalam dua pendekatan yaitu luar jaringan atau luring dan pembelajaran jarak jauh dalam jaringan atau daring. Salah satu pembelajaran wajib yang dapat digunakan yaitu pelajaran Bahasa Indonesia. Mata pelajaran ini telah diajarkan dari jenjang pendidikan Sekolah Dasar (SD) dengan tujuannya secara umum diharapkan dapat membantu mengenalkan budaya, menggunakan kemampuan analitis serta imajinatif, mengemukakan gagasan dan perasaan. Adapun salah satu sumber pelajaran bahasa indonesia yang dapat mengenalkan budaya yaitu cerita rakyat. Cerita rakyat dapat menjadi memori yang kolektif untuk masyarakat lokal di daerah setempat. Hal itu dikarenakan cerita rakyat terjadi di berbagai tempat atau daerah dan belum semuanya dapat terdokumentasi secara baik. Sementara itu, cerita rakyat merupakan bagian sumber kekayaan dari tradisi lisan yang harus dilestarikan,di ungkap,dijaga, digali dan menjadi label dari budaya masyarakat setempat. Setiap daerah perlu menggali kembali cerita rakyat yang berkembang di masyarakat. Dengan begitu, berbagai kisah masa lalu dapat diungkap sebagai aset budaya daerah dan memiliki banyak manfaat dalam kehidupan sehari-hari

Sumber pembelajaran yang ada saat ini memerlukan adanya pengembangan menjadi lebih mudah diakses, digunakan dan dipahami oleh peserta didik. Banyak sekali sumbersumber audio yang dibuat untuk memberikan sarana belajar yang fleksibel. Salah satu bentuk teknologi digital berbasis audio yang berkembang pada generasi milenial saat ini adalah podcast. Penggunaan podcast saat ini telah menyentuh pendidikan yaitu sebagai sumber pembelajaran. Podcast dapat meningkatkan hasil belajar pada beberapa materi, salah satunya adalah kemampuan berbicara dalam bahasa Indonesia. Kemampuan berbicara dalam bahasa indonesia siswa meningkat setelah diberikan sumber podcast. Siswa dapat memilih cerita rakyat yang mereka sukai dan mendengarkannya sebagai bahan materi pembelajaran, sehingga mereka bisa belajar sesuai dengan yang mereka inginkan. Selain itu podcast digunakan sebagai salah satu sumber untuk meningkatkan motivasi belajar siswa. Motivasi belajar siswa cukup meningkat melalui penggunaan podcast sebagai sumber pembelajaran yang dilakukan (Bolliger, Supawan \&Christine, 2010). Podcast juga telah diuji cobakan pada sebuah penelitian oleh Copley (2007) yang menunjukkan bahwa lebih banyak siswa yang mengunduh materi untuk belajar. Podcast menjadikan siswa mengetahui gambaran tentang materi yang akan dibahas lebih mudah dan cepat sehingga siswa lebih siap untuk berdiskusi membahas materi yang ada. Podcast juga bisa menjadi sarana untuk lebih dekat dengan lingkungan sekolah, dimana siswa dapat mendengar cerita rakyat sebagai inspirasinya sehingga siswa lebih termotivasi dalam pembelajaran maupun mengembangkan kemampuan diri.

Andi wicaksono meneliti peran media audio dalam meningkatkan kualitas proses pembelajaran apresiasi cerita pendek. Hasil penelitiannya menunjukan bahwa tujuan pembelajaran bisa tercapai secara optimal dengan perekaman suara untuk cerita pendek yang berindikasi terhadap meningkatnya keaktifan dan keberanian siswa dalam proses pembelajaran (Wicaksono 2017). Selain itu, Ratminingsih meneliti efektifitas media audio pembelajaran bahasa inggris berbasis lagu kreasi dikelas 5 sekolah dasar. Ratminingsih menyatakan bahwa media audio berhasil meningkatkan hasil belajar siswa karena pembelajaran menjadi menyenangkan, menarik dan mudah dipahami sehingga menimbulkan respon positif terhadap pemnfaatan media audio ini (Ratminingsih, 2016). Sedangkan penelitian yang dilakukan oleh Rieka Mustika yang mengkaji media pembelajaran sistem Audio untuk pemberdayaan pendidikan dikomunitas masyarakat. Penelitian ini mencoba untuk mengemas sebuah materi dengan menggunakan komputer dengan nama CAI (Computer Assited Instruction) dengan sistem perekaman digital sehingga dapat menunjang 
pembelajaran untuk mencapai tujuan pembelajaran (Mustika, 2015). Hasil penelitian diatas menunjukan bahwa media audio lebih kepada perekaman materi yang diperuntukan keaktifan belajar siswa dalam mencapai tujuan pembelajaran tanpa melakukan rekonstruksi bahan ajarnya.

Penelitian ini relevan dengan artikel ilmiah 1) Efi Fadilah, dkk; Tahun 2017 yang berjudul "Podcast sebagai Alternatif Distribusi Konten Audio". Penelitian tersebut menunjukan hasil penelitian ini menunjukkan bahwa perkembangan podcast dipengaruhi oleh beberapa aspek, di antaranya pilihan konten yang beragam dan berkualitas, perencanaan dan penentuan topik yang sesuai dengan kebutuhan pendengar serta adanya pendekatan dengan orang atau komunitas yang berpengaruh untuk meningkatkan engagement. eksistensi. Sejalan dengan itu, Adhitya Rol Asmi dkk dalam penelitian yang berjudul "Pengembangan Sumber Pembelajaran Audio Berbasis Podcast Pada Materi Sejarah Lokal di Sumatera Selatan" yang mengemukakan hasil yaitu kelebihan sumber audio berbasis podcast yang telah dikembangkan menjadi sumber pembelajaran sejarah yang dapat digunakan pada saat pembelajaran sejarah terutama bagi mahasiswa Pendidikan Sejarah Universitas Sriwijaya dengan memberikan kemudahan dalam belajar, terutama sumber audio berbasis podcast yang bisa digunakan kapan pun dan dimana pun oleh Mahasiwa, dengan melakukan pengulangan dalam mendengarkan sumber audio, dibagikan di sumber Sosial manapun termasuk aplikasi chatting berupa Whats App, serta dapat diupload pada situs website.

Adapun penelitian ini bertujuan mengembangkan sumber pembelajaran Audio berbasis Podcast pada materi cerita rakyat di SD sebagai upaya untuk mengenalkan budaya dalam pembelajaran Bahasa Indonesia yang disesuaikan dengan kebutuhan dan karakteristik peserta didik.

\section{Metode Penelitian}

Penelitian pengembangan ini menggunakan model Research and Development $(\mathrm{RnD})$. Pengembangan menurut (Borg \& Gall 2003) mengemukakan bahwa proses yang digunakan untuk memvalidasi sumber dan mengembangkan suatu produk penelitian. Sehingga ketika produk sudah dibuat selanjutnya akan divalidasi oleh para ahli agar layak sesuai dengan kriteria pembelajaran. Adapun model pengembangannya yaitu pengembangan ADDIE, model ADDIE. yang terdiri dari 5 langkah, yaitu: analysis, design, development, implementation dan evaluation. Untuk lebih jelasnya dapat diuraikan sebagai berikut:

1) Pada tahap analysis hal yang dilakukan diantaranya: observasi, analisis karakteristik materi dan karakteristik siswa,

2) Pada tahap design hal yang dilakukan diantaranya: membuat naskah cerita rakyat dari sumber terpecaya, dubbing atau merekam suara dengan memilih talent, memilih musik yang sesuai dengan naskah, editing dan bahan penyerta

3) Pada tahap development hal yang dilakukan diantaranya: pengujian dan distribusi dan evaluasi dari para ahli. Serta uji coba pada siswa perorangan dan kelompok kecil dengan perbaikan berdasarkan saran siswa perorangan dan kelompok kecil. Dan yang terakhir uji coba kegiatan pada guru mata kelas dengan perbaikan berdasarkan saran guru kelas.

4) Pada tahap Implementation yang dilakukan adalah melakukan uji coba lapangan terhadap podcast materi cerita rakyat yang dikembangkan.

5) Pada tahap Evaluation, hal yang dilakukan adalah perbaikan sumber belajar podcast berdasarkan uji coba lapangan dan akun podcast pada platform anchor dan spotify serta perbandingan prestasi belajar siswa melalui nilai pretest dan postest. 
Kegiatan yang telah berhasil dikembangkan pada saat perancangan, dilakukan pengujian terlebih dahulu untuk memastikan tidak terjadi kesalahan operasional pada sumber pembelajaran sebelum dilakukan pendistribusian dan uji coba kegiatan. Uji coba terhadap kegiatan pengembangan meliputi: 1) rancangan uji coba, 2) subyek coba, 3) instrumen pengumpulan data, 4) jenis data, dan 5) analisis data. Selanjutnya diuji validitas dan efektivitasnya dengan analisis data berdasarkan hasil: a) uji coba awal yang meliputi validasi ahli isi, sumber dan desain pembelajaran. b) Uji coba perorangan, kelompok kecil, c) Uji coba guru mata pelajaran, dan d) Uji coba lapangan. Uji coba perorangan oleh 3 orang siswa, uji kelompok kecil oleh 12 orang siswa, uji coba guru mata pelajaran oleh seorang guru kelas, dan Uji coba lapangan pada satu kelas yang berjumlah 30 orang.

Hasil review dari ahli isi, ahli sumber belajar dan ahli desain podcast selanjutnya dilakukan revisi berdasarkan saran dan masukan dari para ahli. Hasil revisi kegiatan yang telah diperbaiki selanjutnya dilakukan pengujian pada siswa perorangan dan kelompok kecil. Saat uji coba perorangan dan kelompok kecil dilakukan pemberian kuisioner yang digunakan untuk mengetahui respon siswa perorangan dan kelompok kecil terhadap podcast materi cerita rakyat yang dikembangkan. Respon siswa yang diberikan pada uji perorangan.dan kelompok kecil dijadikan dasar untuk perbaikan kegiatan yang dikembangkan.

Podcast yang telah direvisi tersebut selanjutnya di uji coba kepada guru mata pengampu mata pelajaran pemrograman web, untuk mendapatkan masukan terhadap kegiatan. Selanjutnya Podcast dilakukan uji coba lapangan kepada siswa SDN Picung Remuk II. Pada saat uji coba lapangan ini dilakukan juga pretest dan posttest untuk mengetahui efektivitas sumber belajar yang dibuat. Uji yang dilakukan adalah uji-t, yang menghasilkan perbandingan skor rata-rata antara pretest dan posttest. Penelitian ini menggunakan 3 teknik análisis, yaitu: 1) analisis deskriptif kualitatif untuk mengolah data hasil review ahli isi, ahli sumber belajar, ahli desain pembelajaran, uji coba siswa dan uji coba guru mata pelajaran, 2) análisis deskriptif kuantitatif untuk mengolah data yang diperoleh melalui angka dalam bentuk deskriptif persentase, dan 3) analisis statistik inferensial (uji-t) digunakan untuk menganalisis perbedaan skor-skor pretest dan posttest yang diperoleh saat uji coba lapangan. Untuk menghitung efektifitas podcast yang dikembangkan terhadap peningkatan hasil belajar siswa sebelum dan sesudah menggunakan podcast ini dilakukan dengan membandingkan antara rata-rata hasil pretest dan posttest dengan nilai KKM yang ditetapkan. Apabila nilai posttest dan nilai akhir siswa diatas nilai KKM yang ditetapkan maka podcast yang dikembangkan efektif meningkatkan hasil belajar siswa.

\section{Hasil Penelitian dan Pembahasan Analysis}

Tahapan ini dilakukan dengan melakukan wawancara kepada guru kelas VI di SDN Picung Remuk II yang kemudian diperoleh informasi mengenai kondisi yang ada di sekolah bahwa siswa merasa kurang tertarik dengan cerita rakyat dan menganggap ceritanya sudah ketinggalan zaman. Dalam hal ini guru saat melakukan pembelajaran daring hanya mendokumentasikan cerita rakyat melalui grup Whatsapp sebagai materi pembelajaran sehingga siswa ada yang membaca cerita rakyat ada juga yang tidak. Hal ini tentunya menyebabkan pembelajaran menjadi kurang efektif dan tujuan pembelajaran tidak akan tercapai. Selain itu hal lain yang perlu dianalisis yaitu karakteristik siswa dan karakteristik materi. Berdasarkan analisis yang dilakukan didapatkan informasi sebagai berikut;

1) Karakteristik Materi 
Materi cerita rakyat terdapat pada pembelajaran bahasa Indonesia. Menurut kurikulum 2013, pada pembelajaran Bahasa Indonesia terdapat beberapa kemampuan yang harus dimiliki siswa yaitu kemampuan mendengarkan, membaca, menulis, dan berbicara. Hal ini juga sesuai dengan pendapat Atmazaki (2003:16) "Pada dasarnya tujuan pembelajaran bahasa adalah membimbing perkembangan bahasa siswa secara berkelanjutan melalui proses mendengarkan, berbicara, membaca, dan menulis".

Dalam hal ini materi cerita rakyat ini menekankan pada dua keterampilan bahasa yang harus dikuasai oleh siswa, yaitu kemampuan mendengarkan dan kemampuan berbicara. Kemampuan mendengarkan dibutuhkan untuk menyimak teks lisan yang akan diberikan. Kemampuan mendengarkan terdiri dari tiga elemen yaitu memahami, mempertahankan, dan menanggapi (Sharma, 2011). Sedangkan kemampuan menulis dibutuhkan untuk menyajikan kembali cerita yang telah siswa dengar sesuai dengan tujuan pembelajaran materi ini. Dari penjelasan tersebut, dapat diketahui bahwa materi cerita ini berhubungan dengan kegiatan menyimak yang nantinya siswa dapat menceritakan kembali cerita dari bacaan yang telah didengar.

2) Karakteristik Siswa

Pada dasarnya penggunaan sumber belajar pembelajaran tentu harus disesuaikan dengan karakteristik siswa yang akan menggunakan sumber belajar tersebut. Hal ini dilakukan agar sumber belajar yang dikembangkan menjadi tepat sasaran dan menjadi efektif serta efisien apabila digunakan. Siswa kelas IV SD ratarata berumur antara 10-11 tahun, dimana menurut teori perkembangan anak yang dikemukakan oleh Piaget dalam Nursalim (2007:24) usia tersebut termasuk pada tahap operasional konkrit. Pada tahap operasional konkrit, anak telah memiliki pemahaman yang lebih baik dalam hal hubungan spasial, katagorisasi, dan penalaran. (1) Spasial, contoh perkembangan anak dalam hal ini yaitu anak telah mampu mengingat rute jalan dan penanda jalan dengan baik, (2) Katagorisasi, contoh perkembangan anak dalam hal ini yaitu anak telah mampu menggunakan kemampuan logika dalam mengambil kesimpulan, merangkai suatu urutan, dan inklusi kelas. (3) Penalaran, dikategorikan menjadi 2 yaitu penalaran induktif dan penalaran deduktif. Dimana dalam hal ini anak telah mampu memberikan kesimpulan terhadap suatu hal tanpa harus melihat, menimbang, maupun mengukur suatu objek secara langsung.

Berdasarkan uraian diatas, penggunaan sumber belajar audio podcast untuk siswa kelas VI SD dirasa masih relevan jika digunakan karena siswa telah memasuki tahap operasional konkrit dimana siswa telah dapat memberikan kesimpulan terhadap suatu hal tanpa harus melihat objek secara langsung. Hal ini juga sesuai dengan karakteristik materi meringkas teks lisan yang mengharuskan siswa untuk menyimak dan mendengar bacaan kemudian mereka menceritakannya kembali bacaan yang telah di dengar

\section{Desain}

Tahap desain merupakan langkah awal dalam membuat sumber belajar atau pembuatan semua objek. Pada proses pembuatan sumber belajar audio podcast pada materi cerita rakyat. Langkah pertama yang dilakukan yakni membuat naskah sebagai acuan untuk pembuatan sumber belajar, setelah naskah sudah divalidasi lanjut pada tahap proses dubbing atau merekam suara dengan memilih talent yang sesuai dengan naskah yang diperankan dalam sumber belajar, setelah dubbing Langkah selanjutnya memilih musik yang sesuai dengan naskah. Kemudian pada proses editing. Setelah editing selesai audio podcast di akses melalui anchor agar peserta didik mudah dijangkau saat proses pembelajaran. Sumber belajar 
ini di sertakan dengan bahan penyerta yang digunakan untuk acuan pengguna sumber belajar atau sebagai informasi sumber belajar tersebut

\section{Development}

Setelah dilakukan perancangan, maka pada tahap ini sumber belajar akan dikembangkan sesuai rancangan yang tersebut. Selanjutnya sumber belajar akan divalidasi oleh validator dengan menggunakan instrumen validasi telah yang disusun. Dari hasil validasi maka didapatkan data sebagai berikut :

1) Hasil review ahli isi menunjukkan validitas podcast pada materi cerita rakyat yang dikembangkan dari aspek isi atau materi yang disajikan berkualifikasi sangat baik dengan memperoleh persentase sebesar 94\%. Hal ini berarti isi atau materi yang disajikan dalam podcast sesuai dan layak dibelajarkan kepada siswa. Hasil penilaian terhadap bahan penyerta memperoleh persentase sebesar $80 \%$ dan berkualifikasi baik.

2) Hasil review ahli sumber belajar digunakan untuk menilai kerelevanan sumber belajar yang digunakan dalam menjelaskan atau mengkonkretkan isi dari setiap materi mencapai kesesuaian sebesar $93.25 \%$, berada dalam kategori sangat baik dan tidak perlu direvisi. Hasil penilaian terhadap bahan penyerta memperoleh persentase 90,33\% dan berkualifikasi sangat baik. Perbaikan dilakukan terhadap intonasi cerita rakyat yang kurang pas.

3) Hasil review ahli desain pembelajaran menunjukkan tingkat validitas podcast pada materi cerita rakyat yang dikembangkan memperoleh presentase sebesar $83 \%$, berada dalam kategori baik dan sedikit direvisi. Hasil penilaian terhadap bahan peneyrta adalah sebesar 90,58\% dan berada pada kualifikasi baik dan sedikit direvisi. Perbaikan dilakukan terhadap Tanya jawab dan diskusi tentang nilai karakter yang akan dikembangkan dalam pembelajaran.

4) Hasil uji perorangan dan uji kelompok kecil menunjukkan tingkat validitas sumber berdasarkan hasil rata-rata tanggapan siswa perorangan dan kelompok kecil menunjukkan persentase masing-masing sebesar $96.67 \%$ dan $94.17 \%$ dan berada pada kualifikasi sangat baik dan tidak perlu direvisi. Sedangkan hasil rata-rata tanggapan siswa perorangan dan kelompok kecil terhadap bahan penyerta menunjukkan persentase masing-masing sebesar 97.92 dan 98.96 dengan kualifikasi sangat baik dan tidak perlu direvisi.

5) Hasil uji coba pada guru kelas terhadap sumber belajar podcast yang dikembangkan menunjukkan tingkat validitas sumber belajar pada kualifikasi sangat baik dengan persentase sebesar $100 \%$ sehingga tidak perlu direvisi. Hasil tanggapan terhadap bahan penyerta menunjukkan prosentase sebesar 100\% dengan kualifikasi sangat baik sehingga tidak perlu direvisi.

\section{Implementation}

Pada tahap implementasi, dilakukan uji coba lapangan kepada siswa. Uji lapangan dilakukan dengan memberikan angket kepada siswa mengenai media audio. Angket berisikan beberapa butir soal yang disebar melalui link google form.

Hasilnya menunjukkan tingkat validitas media yang dikembangkan berada pada kualifikasi sangat baik dengan persentase sebesar $92,11 \%$. Hal ini dikarenakan jembatan penghubung antara kegiatan pendahuluan dan kegiatan inti melalui sumber belajar kurang sesuai dilakukan dalam kegiatan pembelajaran. Hasil tanggapan juga ada terhadap bahan penyerta yang menunjukkan persentase sebesar $100 \%$ dengan kualifikasi sangat baik sehingga tidak perlu direvisi. 


\section{Evaluation}

Pada model ADDIE, tahapan evaluasi tidak hanya dilaksanakan pada akhir melainkan pada setiap tahapan. Mulai dari tahap analisis, design, pengembangan, dan implementasi. Evaluasi dilakukan untuk memperbaiki media yang dikembangkan. Berikut adalah rincian hasil evaluasi yang telah dilakukan pada penelitian ini :

Tabel 1. Hasil Evaluasi Uji Lapangan Sebelum dan Sesudah

\begin{tabular}{|c|c|}
\hline Sebelum Uji Lapangan & Rekomendasi Setelah Uji Lapangan \\
\hline $\begin{array}{l}\text { Jembatan penghubung antara kegiatan } \\
\text { pendahuluan dan kegiatan inti melalui } \\
\text { sumber belajar kurang sesuai dilakukan } \\
\text { dalam kegiatan pembelajaran. }\end{array}$ & $\begin{array}{l}\text { Penggunaan apersepsi yang kontekstual } \\
\text { dengan kehidupan sehari-hari }\end{array}$ \\
\hline
\end{tabular}

Adapun hasil prestasi belajar yang diperoleh dengan menggunakan pretest dan postest, menunjukkan terjadinya peningkatan prestasi belajar siswa. Hal ini ditunjukan sebelum menggunakan sumber belajar podcast dengan sesudah menggunakan sumber belajar podcast. Hasil rata-rata nilai pretest sebesar 26,3 berada dibawah KKM yang ditetapkan sebesar 75, sedangkan hasil rata-rata posttest siswa adalah sebesar 86,92 dan berada pada kategori B+(86-90), Hal ini menunjukkan bahwa sumber belajar podcast untuk membantu meningkatkan hasil belajar siswa.

Berdasarkan hasil uji-t dua sampel berpasangan (paired samples t-test) menunjukkan bahwa nilai signifikansi yang diperoleh adalah sebesar 0,001 kurang dari signifikansi yang telah ditetapkan yaitu sebesar 0,05 sehingga $\mathrm{H} 0$ ditolak dan $\mathrm{H} 1$ diterima. Ini berarti terdapat perbedaan yang signifikan terhadap hasil belajar siswa antara sebelum belajar dengan menggunakan sumber belajar podcast dengan setelah belajar dengan menggunakan sumber belajar podcast.

\section{Kesimpulan}

Berdasarkan hasil analisis data dan pembahasan pada penelitian pengembangan ini, maka dapat diambil simpulan penggunaan podcast sebagai sumber belajar berbasis audio dalam proses pembelajaran berpengaruh secara positif dan signifikan terhadap tingkat penguasaan materi. Hasil rata-rata posttest siswa sebesar masing-masing 86,92 berada diatas nilai KKM yang ditetapkan sebesar 75, artinya penerapannya sangat efektif untuk meningkatkan hasil belajar siswa.

\section{Saran}

Saran yang disampaikan berdasarkan hasil penelitian ini antara lain; (1) Dalam pemanfaatannya media audio ini dapat dimanfaatkan selama proses pembelajaran dengan materi cerita rakyat, bertujuan untuk dapat memotivasi belajar siswa sehingga siswa dapat termotivasi dan semangat dalam belajar. (2) Pengembangan media audio podcast selanjutnya diharapkan mampu mengembangkan produk yang lebih inovatif dan kreatif dalam segi kualitas produk. (3) Pengembangan media audio podcast pada materi cerita rakyat ini digunakan di sekolah lain dengan mengidentifikasi kebutuhan kembali, terutama pada karakteristik pengajar, karakteristik peserta didik, sarana prasarana dan lain-lain yang ada di sekolah tersebut. 


\section{Daftar Pustaka}

Bolliger, Supawan \& Christine. (2010). Impact of Podcasting on Student Motivation in The Online Learning Environment. Computers Education. 55: 714 - 722.1

Borg \& Gall, 2003. Education Research New York : Allyn and Baco

Copley, Jonathan. (2007). Audio and video podcast of lectures for campus-based student: production and evaluation of student use. Innovation in Education and Teaching International, 44 (4): 387 - 399

Fadilah, Efi., dkk. (2017). Podcast sebagai Alternatif Distribusi Konten Audio. Kajian Jurnalisme, $\quad$ Vol. $\quad 1 \quad$ No. $1 . \quad$ Diakses: http://jurnal.unpad.ac.id/kajianjurnalisme/article/view/10562

Mustika, R. (2016). Media Pembelajaran Sistem Audio untuk Pemberdayaan Pendidikan di Komunitas masyarakat. Masyarakat Telematika Dan Informasi: Jurnal Penelitian Teknologi Informasi dan Komunikasi, 6 (1) , pp.57-68. https://mti.kominfo. go.id/index.php/mti/article/view/75/63

Roll, A., dkk (2019). Pengembangan Sumber Pembelajaran Audio Berbasis Podcast Pada Materi Sejarah Lokal Di Sumatera Selatan. Diakses: file://C:/Users/ASUS/Downloads/21017-49653-1-PB.pdf

Ratminingsih, N.M. (2016). Efektivitas media audio pembelajaran bahasa Inggris berbasis lagu kreasi di kelas lima sekolah dasar. JPI (Jurnal Pendidikan Indonesia), 5(1), pp.27-38. DOI: http://dx.doi. org/10.23887/jpi-undiksha.v5i1.8292

Sugiyono (2017). Metode Penelitian Kuantitatif.Yogyakarta: Alfabeta

Wicaksono, Andi. (2017). Media Audio dalam meningkatkan kualitas proses pembelajaran apresiasi cerita pendek. Jurnal Shahih, Vol 2 No 1, Januari-Juni 2017, hal: 67-78. DOI : 10.22515/ shahih.v2i1.670 